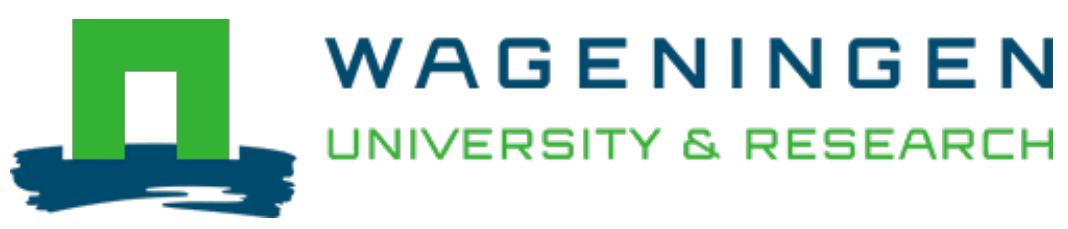

\title{
The impacts of constructivist learning design and learning analytics on students' engagement and self-regulation
}

Innovations in Education and Teaching International

Banihashem, Seyyed Kazem; Farrokhnia, Mohammadreza; Badali, Mehdi; Noroozi, Omid

https://doi.org/10.1080/14703297.2021.1890634

This article is made publicly available in the institutional repository of Wageningen University and Research, under the terms of article $25 \mathrm{fa}$ of the Dutch Copyright Act, also known as the Amendment Taverne. This has been done with explicit consent by the author.

Article 25 fa states that the author of a short scientific work funded either wholly or partially by Dutch public funds is entitled to make that work publicly available for no consideration following a reasonable period of time after the work was first published, provided that clear reference is made to the source of the first publication of the work.

This publication is distributed under The Association of Universities in the Netherlands (VSNU) 'Article $25 \mathrm{fa}$ implementation' project. In this project research outputs of researchers employed by Dutch Universities that comply with the legal requirements of Article $25 \mathrm{fa}$ of the Dutch Copyright Act are distributed online and free of cost or other barriers in institutional repositories. Research outputs are distributed six months after their first online publication in the original published version and with proper attribution to the source of the original publication.

You are permitted to download and use the publication for personal purposes. All rights remain with the author(s) and / or copyright owner(s) of this work. Any use of the publication or parts of it other than authorised under article $25 \mathrm{fa}$ of the Dutch Copyright act is prohibited. Wageningen University \& Research and the author(s) of this publication shall not be held responsible or liable for any damages resulting from your (re)use of this publication.

For questions regarding the public availability of this article please contact openscience.library@,wur.nl 


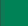

\section{The impacts of constructivist learning design and learning analytics on students' engagement and self-regulation}

\section{Seyyed Kazem Banihashem, Mohammadreza Farrokhnia, Mehdi Badali \& Omid Noroozi}

To cite this article: Seyyed Kazem Banihashem, Mohammadreza Farrokhnia, Mehdi Badali \& Omid Noroozi (2021): The impacts of constructivist learning design and learning analytics on students' engagement and self-regulation, Innovations in Education and Teaching International, DOI: $10.1080 / 14703297.2021 .1890634$

To link to this article: https://doi.org/10.1080/14703297.2021.1890634

\section{Published online: 26 Feb 2021.}

\section{Submit your article to this journal $\sqsubset$}

Џll Article views: 140

Q View related articles ¿

View Crossmark data ¿ 


\title{
The impacts of constructivist learning design and learning analytics on students' engagement and self-regulation
}

\author{
Seyyed Kazem Banihashem (D) ${ }^{\mathrm{a}, \mathrm{b}}$, Mohammadreza Farrokhnia ${ }^{\mathrm{b}}{ }^{\mathrm{b}}$, Mehdi Badalic \\ and Omid Noroozi (D) $^{\mathrm{b}}$ \\ aEducational Technology, Allameh Tabataba'i University, Tehran, Iran; 'bducation and Learning Sciences, \\ Wageningen University and Research, Wageningen, The Netherlands; 'Faculty of Humanities, Tarbiat \\ Modares University, Tehran, Iran
}

\begin{abstract}
So far, the synergistic relationship between learning design and learning analytics and its impact on learners' educational practices have been investigated. However, little work has been done to show how integrated learning design based on constructivism learning theory and learning analytics can affect learners' engagement and self-regulation. Thus, this study aimed to investigate the effect of the Constructivist Learning Design and Learning Analytics (CLDLA) Model on learners' engagement and self-regulation. In this experimental study, 50 graduate students at Iranian' Allameh Tabataba'i University were asked to participate in a Moodle course called "Teaching Skills" and fill out Agentic Engagement Scale and Self-Regulation Questionnaires in two steps as a pre-test and posttest measurements. Analysis of the data indicated that the CLDLA model has a positive impact on learners' engagement and selfregulation. Based on the results, recommendations for further research and educational practices are suggested.
\end{abstract}

\section{KEYWORDS}

Constructivism; learning design; learning analytics; engagement; self-regulation; higher education

\section{Introduction}

Learning Management System (LMS) as a Web 2.0 online platform plays an essential role in higher education to deliver courses (Hu et al., 2020). LMS facilitates flexible learning beyond time and distance, supports collaborative learning, and interaction through discussion forums and chat sessions (Chaubey \& Bhattacharya, 2015). However, using LMS like any other online learning environment has its own challenges. One of the main challenges is how to commit learners to engage and self-regulate in learning activities (Martin \& Bolliger, 2018; Wong et al., 2019). In online courses, teachers struggle to motivate students to actively participate, involve, and engage in learning activities (Kahn et al., 2017). Participants in online learning environments have difficulties using selfregulated learning strategies (Wong et al., 2019). They have difficulties planning, organising, regulating, directing, and monitoring their learning process (Cho \& Shen, 2013).

Scholars showed that students' active engagement in the learning process improves their communication skills, learning outcomes, attention and increase learning life skills 
(Abubakar et al., 2017; Khalifeh et al., 2020; Liu et al., 2019). Self-regulated learning is another crucial ability for students' success in online learning environments (Kalenda \& Vávrová, 2016). Self-regulated learning helps learners monitor, regulate, and control their cognition, motivation, and behaviour (Hofmann et al., 2012). Prior research showed that engagement and self-regulated learning are positively associated with students' academic success in online courses (Abubakar et al., 2017; Broadbent \& Poon, 2015; Cho \& Shen, 2013; Kahn et al., 2017; Pardo et al., 2016). Thus, teachers must understand how to encourage students to engage and involve actively in online learning environments.

Learning analytics (LA) as a data-oriented field of study offers noticeable benefits for online learning such as improving students' engagement and self-regulation, understanding students learning habits, providing real-time and personalised feedback, and identify students' at risk of failure (Akçapınar et al., 2019; Heller, 2020; Pardo et al., 2019; Vytasek et al., 2020). However, one of the critical challenges is the lack of attention to pedagogical and theoretical foundations in the use of LA (Banihashem et al., 2018, 2019; Gašević et al., 2016; Knight et al., 2014; Wiley et al., 2020; Wise, 2014). In previous studies, LA was mostly used as a tool to support and inform the design of learning, engagement, and self-regulation (see Calonge et al., 2019; Chen et al., 2018; Heller, 2020; Holmes et al., 2019; Ifenthaler et al., 2018; Kim et al., 2018; Persico \& Pozzi, 2015; Roll \& Winne, 2015; Toro-Troconis et al., 2019; Viberg et al., 2020; Winne, 2017). However, it lacks sound theory-oriented pedagogy (Wiley et al., 2020). In this regard, Wise (2014) posited that LA would not truly influence teaching and learning and fulfill expectations of revolutionising education if it is not considered and designed in a larger instruction pattern. Thus, there are still concerns regarding how LA interacts with teachers' learning design and supports learners' engagement and self-regulation insightfully.

This study used a constructivist theory-oriented model called Constructivist Learning Design and Learning Analytics (CLDLA) to determine its possible potentials to support higher education students' engagement and self-regulation skills for learning in LMS (see Figure 1). The CLDLA model provides an operational framework for teachers and learners to apply LA in online constructivist learning environments (Banihashem, 2020). This model embeds LA within a constructivist learning design model and contributes to bridging theory and practice in LA by providing a pedagogical and theoretical framework for LA. The CLDLA model consists of seven main steps, respectively, from subject to evaluation that reflects the constructivist learning design process, and each step has its own LA indications.

The design process of this model is in line with the constructivist principles stated by scholars such as Vygotsky (Hodson \& Hodson, 1998), Jonassen (1999), Merrill (2002), and Bybee et al. (2006). For example, in line with Merrill's first principles of instruction (Merrill, 2002) and Jonassen's (1999) constructivist learning environment design, the first step in the CLDLA model is subject where a question, problem, vague situation, project, or task is presented for students. It is essential to know who the students are to provide the best subject for them, which in this case, academic data, academic background data, and psychological data could help. The analytics level in the first step is mainly descriptive, and clustering, classification, and descriptive analysis are used as analytics techniques when data are collected. Reported findings in the first step can be used to optimise learning, diagnosis, decision-making, and motivation. Thus, both teachers and learners are benefited from LA in the first step. 


\begin{tabular}{|c|c|c|c|c|c|c|c|}
\hline & & \multicolumn{6}{|c|}{ Learning Analytics (LA) } \\
\hline & Subcategory & Data & Analytics level & Analytics techniques & Process & Objectives & Stakeholders \\
\hline Subject & \begin{tabular}{|c|} 
Question, \\
problem, vague \\
situation, project, \\
task \\
\end{tabular} & $\begin{array}{l}\text { Academic data, academic } \\
\text { background data, } \\
\text { psychological data }\end{array}$ & Descriptive & $\begin{array}{l}\text { Descriptive analysis, classification, } \\
\text { clustering }\end{array}$ & Collect, analysis, report & $\begin{array}{l}\text { Learning optimization, } \\
\text { diagnosis, motivation, } \\
\text { decision-making }\end{array}$ & $\begin{array}{l}\text { Teacher, } \\
\text { learner }\end{array}$ \\
\hline Demonstration & \begin{tabular}{|c|} 
Provide resources, \\
directions, \\
explanation
\end{tabular} & $\begin{array}{l}\text { Academic data, academic } \\
\text { background data, } \\
\text { psychological data }\end{array}$ & Descriptive & $\begin{array}{c}\text { Descriptive analysis, classification, } \\
\text { clustering }\end{array}$ & Collect, analysis, report & $\begin{array}{l}\text { Motivation, learning } \\
\text { optimization }\end{array}$ & Teacher \\
\hline Activation & $\begin{array}{l}\text { Exploration, } \\
\text { knowledge } \\
\text { construction, } \\
\text { active learning } \\
\text { techniques }\end{array}$ & $\begin{array}{l}\text { Meaningful data, } \\
\text { performance data, } \\
\text { psychological data }\end{array}$ & $\begin{array}{l}\text { Descriptive, } \\
\text { diagnostic, } \\
\text { prescriptive }\end{array}$ & $\begin{array}{c}\text { Descriptive analysis, classification, } \\
\text { clustering, decision tree, sequential } \\
\text { pattern discovery, association rule } \\
\text { mining }\end{array}$ & $\begin{array}{c}\text { Collect, analysis, report, } \\
\text { interpretation }\end{array}$ & $\begin{array}{c}\text { Diagnosis, awareness of } \\
\text { learning process, feedback, } \\
\text { personalization, decision- } \\
\text { making, self-regulation }\end{array}$ & Learner \\
\hline 总 & $\begin{array}{l}\text { Participation, } \\
\text { cooperation, } \\
\text { engagement }\end{array}$ & $\begin{array}{l}\text { Interaction data, } \\
\text { performance data, } \\
\text { meaningful data }\end{array}$ & $\begin{array}{l}\text { Descriptive, } \\
\text { diagnostic, } \\
\text { prescriptive }\end{array}$ & $\begin{array}{l}\text { Descriptive analysis, classification, } \\
\text { clustering, social network analysis, } \\
\text { decision tree, sequential pattern } \\
\text { discovery, association rule mining }\end{array}$ & $\begin{array}{c}\text { Collect, analysis, report, } \\
\text { interpretation }\end{array}$ & $\begin{array}{c}\text { Diagnosis, awareness of } \\
\text { learning, feedback, learning } \\
\text { optimization }\end{array}$ & $\begin{array}{l}\text { Teacher, } \\
\text { learner }\end{array}$ \\
\hline$\frac{\frac{6}{8}}{\frac{0}{0}}$ & $\begin{array}{l}\text { Guidance, } \\
\text { support, } \\
\text { scaffolding, } \\
\text { feedback }\end{array}$ & $\begin{array}{l}\text { Interaction data, } \\
\text { performance data }\end{array}$ & $\begin{array}{l}\text { Descriptive, } \\
\text { diagnostic, } \\
\text { predictive, } \\
\text { prescriptive }\end{array}$ & $\begin{array}{c}\text { Descriptive analysis, social network } \\
\text { analysis, regression, predictive } \\
\text { modeling, classification, clustering, } \\
\text { decision tree, association rule } \\
\text { mining, factor analysis }\end{array}$ & $\begin{array}{c}\text { Collect, analysis, report, } \\
\text { interpretation }\end{array}$ & $\begin{array}{c}\text { Diagnosis, awareness of } \\
\text { learning, feedback, learning } \\
\text { optimization }\end{array}$ & Teacher \\
\hline $\begin{array}{l}\text { Application/ } \\
\text { Interpretation }\end{array}$ & $\begin{array}{c}\text { Solving real-life } \\
\text { problems, } \\
\text { knowledge } \\
\text { application, higher } \\
\text { order thinking }\end{array}$ & Performance data & $\begin{array}{l}\text { Descriptive, } \\
\text { diagnostic, } \\
\text { prescriptive }\end{array}$ & $\begin{array}{c}\text { Descriptive analysis, classification, } \\
\text { clustering, sequential pattern } \\
\text { discovery, decision tree, association } \\
\text { rule mining }\end{array}$ & $\begin{array}{c}\text { Collect, analysis, report, } \\
\text { interpretation }\end{array}$ & $\begin{array}{l}\text { Diagnosis, awareness of } \\
\text { learning, personalization }\end{array}$ & Learner \\
\hline Evaluation & $\begin{array}{l}\text { Self-assessment, } \\
\text { formative } \\
\text { assessment, } \\
\text { summative } \\
\text { assessment, } \\
\text { reflection }\end{array}$ & $\begin{array}{l}\text { Meta-data, performance } \\
\text { data, meaningful data, } \\
\text { academic data, } \\
\text { psychological data }\end{array}$ & $\begin{array}{l}\text { Descriptive, } \\
\text { diagnostic, } \\
\text { predictive, } \\
\text { prescriptive }\end{array}$ & \begin{tabular}{|} 
Descriptive analysis, social network \\
analysis, regression, predictive \\
modeling, classification, clustering, \\
decision tree, association rule \\
mining, factor analysis
\end{tabular} & $\begin{array}{c}\text { Collect, analysis, report, } \\
\text { interpretation }\end{array}$ & $\begin{array}{c}\text { Diagnosis, personalization, } \\
\text { decision-making, reflection, } \\
\text { feedback, monitoring, } \\
\text { assessment }\end{array}$ & $\begin{array}{l}\text { Teacher, } \\
\text { learner, } \\
\text { administrator, } \\
\text { course } \\
\text { designer, } \\
\text { parents }\end{array}$ \\
\hline
\end{tabular}

Figure 1. The CLDLA model (adopted from Banihashem, 2020, p. 149).

\section{Research questions}

Based on the argumentation above, stimulating active engagement and self-regulated learning opportunities for students are the two key issues that should be considered in LMS platforms. Thus, this study sought to determine whether the theory-oriented CLDLA model could improve students' engagement and self-regulation skills. The following research questions were formulated to guide this study.

- RQ1. To what extent the CLDLA model has a significant impact on learners' engagement?

- RQ2. To what extent the CLDLA model has a significant impact on learners' selfregulation?

\section{Materials and methods}

\section{Participants}

A pre-test-post-test control group research design was used in this study to address the research questions. It means that the learning outcomes of two groups of students (i.e., control and experimental) were measured in two phases: before and after using the module. The study's participants were 50 graduate students from Allameh Tabataba'i University who were teachers and enrolled for the Moodle course called 'Teaching Skills'. Students were randomly assigned to two conditions, with 25 
participants for each condition. One group was taught with a constructivist learning environment condition (i.e., control group), and the other group was taught with constructivist learning design and learning analytics conditions (i.e., experimental group). The mean age of the participants was $27.08(\mathrm{SD}=1.86)$ years. Almost $74 \%$ $(\mathrm{N}=37)$ of the participants were female, and only $26 \%(\mathrm{~N}=13)$ were male. Most participants have less than five years of teaching experience $(\mathrm{N}=38,76 \%)$, and about $24 \%$ of the participants have more than five years of teaching experience $(\mathrm{N}=$ $12,24 \%)$. To comply with the ethical aspects: (1) participants were notified that the study results would only be used for research purposes. (2) All participants were allowed to quit the research study; however, no participants declined participation. (3) Researchers immediately omitted all identification data such as students id after data collection to make sure that results could not be linked to any individual students.

\section{Learning environment}

The study took place in a MoodleCloud platform in which two MoodleCloud sites were developed to run the course. The course 'Teaching Skills' was presented to improve the participants' teaching skills. The language for the course was Persian, and there were no prerequisites for participating in the course. The course was run in two sessions within two weeks. The design of the course and phases of the study is presented in Table 1.

It is to be noted that only participants with the CLDLA condition had access to see the visualisations for the social interactions in the discussion forum. The course instructors had access to some academic information about participants with the CLDLA condition. Moreover, they were able to see which participant with the CLDLA condition saw the course, the number of videos watched, last access to the course,

Table 1. Phases of the study.

\begin{tabular}{|c|c|c|}
\hline Phase & Task(s) description & Time \\
\hline $\begin{array}{l}\text { Introduction and } \\
\text { pre-test }\end{array}$ & $\begin{array}{l}\text { Students in both groups received verbal and textual explanations about the course and } \\
\text { were asked to completed demographic information and fill out the self-regulation } \\
\text { questionnaire and agentic engagement scale. Experimental condition group was } \\
\text { asked to complete an academic data questionnaire. }\end{array}$ & $\begin{array}{l}30 \mathrm{~min}, \\
15 \mathrm{~min}\end{array}$ \\
\hline First session & $\begin{array}{l}\text { Two topics were discussed, and a recorded video was uploaded for each topic, including } \\
\text { (a) verbal communications in teaching (video part I and video part II) and (b) non- } \\
\text { verbal communications in teaching (video part I and video part II). A text file uploaded } \\
\text { for more explanation. For both groups and the course materials, one course facilitator } \\
\text { was responsible for facilitating the learning process. Students were asked to discuss } \\
\text { with their peers about the topics. }\end{array}$ & $\begin{array}{l}9 \text { min, } \\
10 \text { min, } \\
30 \text { min, } \\
30 \text { min }\end{array}$ \\
\hline Second session & $\begin{array}{l}\text { The topic was about speech in the class in which three sub-topics were discussed, and } \\
\text { recorded video was provided after an introductory explanation to the second session } \\
\text { (a) speech principles in the class, (b) the body of the speech, and (c) conclusion in the } \\
\text { speech. One course facilitator was responsible for facilitating the learning process. } \\
\text { Students were asked to upload a 5-minute video concerning the discussed topic in } \\
\text { their uploaded video and discuss their performance with their peers. }\end{array}$ & $\begin{array}{l}6 \mathrm{~min} \\
8 \mathrm{~min} \\
8 \mathrm{~min} \\
45 \mathrm{~min}\end{array}$ \\
\hline Post-test & $\begin{array}{l}\text { Students were asked to fill out a self-regulation questionnaire and agentic engagement } \\
\text { scale to assess their engagement and self-regulation. }\end{array}$ & $30 \mathrm{~min}$ \\
\hline
\end{tabular}


the time spent in the course, and whether they posted any words or ideas in the discussion forum or not.

\section{Measurement tools}

In the MoodleCloud platform, different kinds of data were collected about participants' activities, which basically can be called LMS data. LMS data such as data about participants' interaction in the discussion forum, number of logging in and logging out, the number of watching recorded videos, last seen and last access of the course, and time spent on the course. An online self-reported questionnaire was also designed, and participants were asked to fill out the questionnaire before beginning the course. This self-reported questionnaire comprises 12 items that collect data about the type of gender, known languages, field of study, level of earned degree, teaching experiences, learning style, attitude about teaching, experiences of passing similar courses, and some other related data.

\section{Student engagement}

Reeve and Tseng's (2011) Agent Engagement Scale was used to investigate students' engagement. This scale includes 22 items that assess four subscales: agentic engagement, behavioural engagement, emotional engagement, and cognitive engagement. Agentic engagement is defined as 'students' constructive contribution to the flow of the instruction they receive' (Reeve \& Tseng, 2011, p. 258). This subscale comprises 5 items related to students' contributions during the teaching and learning process. The behavioural engagement (5 items) measures students' attempts to learn and participate in activities (Mameli \& Passini, 2017). The emotional engagement is made up of 4 items that estimate students' desire and like to learn and involvement in-class activities. The cognitive engagement includes eight items and investigates 'students' use of significant information-processing strategies in learning' (Mameli \& Passini, 2017, p. 532). Participants were asked to demonstrate their agreement level on a 7-point Likert scale (from $1=$ strongly disagree to 7 = strongly agree) to answer this scale. Reeve and Tseng (2011) confirmed the scale's validity and reported strong reliability (alpha $=.94$ ). In the present study, the scale's reliability was also measured by the alpha coefficient formula and showed to be strong (alpha $=.91$ ). The Agent Engagement Scale was employed in two phases: a pre-test and a post-test.

\section{Students' self-regulation}

Students' self-regulation was investigated by Brown et al. (1999) Self-Regulation Questionnaire. This questionnaire is made up of 63 items on a 5-point Likert scale (from 1 = strongly disagree to 5 = strongly agree). 26 items out of 63 items are scored reversely. The questionnaire's subsequent analyses indicated that the scale entails one main component rather than specific factors (Brown et al., 1999). Although the test-retest reliability and internal consistency of the Self-Regulation were reported to be high (see Brown et al., 1999), the questionnaire's reliability was also measured in the present study using the 
alpha coefficient formula and showed to be high (alpha $=.90$ ). Data for self-regulation were collected in two steps, including pre-test and post-test.

\section{Analysis}

Descriptive analysis was performed to analyse the Moodle data and academic background data. Besides, an ANCOVA test was conducted in SPSS to compare the differences between pre-test and post-test of the two conditions regarding their engagement and self-regulation. The reason why ANCOVA was used is to control initial differences between the two groups (experimental and control) regarding engagement and self-regulation.

\section{Results}

Descriptive analysis showed that for the engagement, the participants' mean score in the experimental condition group was increased from $78.80(\mathrm{SD}=3.24)$ in the pre-test to 80.32 (SD = 3.48) in the post-test. The participants' mean score in the experimental condition group was raised from $37.88(S D=1.90)$ in pre-test to $40.16(S D=1.90)$ in the post-test for self-regulation. In contrast, changes in the control condition group for both variables were minor. For engagement, mean score from pre-test $(M=79.20$, $S D=2.34)$ to post-test $(M=79.56, S D=2.21)$ only increase 0.36 and for self-regulation, mean score from pre-test $(M=37.44, S D=2.10)$ to post-test $(M=37.68, S D=2.34)$ only increase 0.24 .

RQ1. To what extent the CLDLA model has a significant impact on learners' engagement?

Table 2 shows that differences between the two conditions in terms of learners' engagement are significant $(F=9.839, P<.003)$. This means that the learners in the experimental condition were significantly more engaged in the course than in the control condition $(P<.001)$.

RQ2. To what extent the CLDLA model has a significant impact on learners' selfregulation?

Table 2. Differences between the two conditions in terms of learners' engagement.

\begin{tabular}{lccccc}
\hline Source & Sum of Squares & df & Mean Square & F & Sig \\
\hline Pre-Test & 333.388 & 1 & 333.388 & 205.599 & .000 \\
Groups & 15.955 & 1 & 15.955 & 9.839 & .003 \\
Error & 76.212 & 47 & 1.62 & & \\
Total & 319,937 & 50 & & & \\
\hline
\end{tabular}

Table 3. Differences between the two conditions in terms of learners' self-regulation.

\begin{tabular}{lccccc}
\hline Source & Sum of Squares & df & Mean Square & F & Sig \\
\hline Pre-Test & 136.120 & 1 & 136.120 & 77.37 & .000 \\
Groups & 54.977 & 1 & 54.977 & 31.252 & .000 \\
Error & 82.68 & 47 & 1.759 & & \\
Total & 76,034 & 50 & & & \\
\hline
\end{tabular}


Results in Table 3 show that differences between the two conditions in terms of learners' self-regulation are significant $(F=31.252, p<.000)$. This means that the experimental condition learners were more self-regulated than learners in the control condition $(p<.001)$.

\section{Discussion}

As the field of LA continues to evolve, it is necessary to conduct experimental studies in order to explore LA connection with learning design based on learning theories and their impacts on educational practices. This study was carried out to explore the effects of the CLDLA model on learners' engagement and self-regulation. The results indicated that the CLDLA model has a positive impact on learners' engagement. This is in line with previous studies highlighting the positive impacts of LA on engagement (e.g., Calonge et al., 2019; Chen et al., 2018; Toro-Troconis et al., 2019; Vytasek et al., 2020). Although previous studies confirmed that LA plays a positive role in improving students engagement, they also expressed concerns that LA implications for students' engagement could be threatened by LA technological determinism if these data findings have not been viewed and interpreted through a wider pedagogical and learning lens (Knight et al., 2014). LA in the CLDLA model relies on constructivism learning theory that informs teachers and students to make pedagogy-oriented decisions where LA is underpinned, guided, and interpreted by a pedagogical theory (Banihashem et al., 2019). It means that the application of the CLDLA model could reduce the risk of technological and mechanical interpretations in the use of LA.

Moreover, the current study results also indicated that the CLDLA model could provide an operational framework to fully support students' active participants in the class and engagement in the knowledge construction based on constructivist learning design principles and process. Also, our findings showed that the CLDLA model has a positive impact on learners' self-regulation. This implies that the CLDLA model can give learners the potential to regulate their behaviour activities. This finding is in line with prior research that emphasises the positive effects of LA on self-regulation (see Heller, 2020; Kim et al., 2018; Roll \& Winne, 2015; Viberg et al., 2020; Winne, 2017). According to scholars, although self-regulation is a complex behaviour and evaluation and interpretation of self-regulation activities in online learning environments is challenging, LA is instrumental in addressing this challenge (Roll \& Winne, 2015), especially if analytics on data be seen within a theoretical framework (Viberg et al., 2020).

In the CLDLA model, LA reports are interpreted based on the constructivism learning theory principles, which could help teachers better understand what data means for them. For example, the CLDLA model helps teachers with learner analysis, where data about learners' academic background and psychological features are collected, analysed, and interpreted based on constructivism learning theory. In this case, teachers can have better interpretations, more than numeric reports, and in-depth insights into who the learners are. In another example, constructivist interpretations of students' interaction and performance data can inform teachers better understand how learners are doing and whether they are doing as it is planned in learning design. This implies the CLDLA's potential in providing a pedagogical interpretation of students' self-regulation activities and informing teachers' learning design. 


\section{Conclusion}

In this experimental study, we determined how the integration model of LA and learning design based on constructivist learning theory could affect learners' engagement and self-regulation. In this regard, our results provide insights for effective implementation of LA within learning design to improve students' engagement and self-regulation in online learning environments.

The current study also had some limitations. First, the data we used in this study only represents one course at a particular university. Also, participants of this study were a relatively small number of graduate students with teaching backgrounds. Moreover, since higher education students come from different backgrounds, the results obtained in this study cannot be generalised to other courses or students. Therefore, the scalability of the CLDLA model is under question. Second, in this study, we mostly relied on Moodle and surveyed data due to limited access to qualitative data such as data on students' cognitive processes. Failure to collect and investigate this data may limit the CLDLA model's validity since it is a constructivist oriented model. Third, self-regulation is a complex concept that requires a high metacognitive process (Russell \& Warner, 2017), and also engagement is something more than simply involvement, and it requires feelings and sense-making (Trowler, 2010). This means that we should not claim that the CLDLA model is the only reason students' self-regulation and engagement were improved in the group with experimental conditions.

Notwithstanding the important implications of this study, several limitations paving the way to further research should be acknowledged. First, we suggest conducting more empirical studies on the impacts of the CLDLA model on other educational practices to further explore its feasibility and effectiveness in constructivist online learning environments. Second, this study was implemented through a Moodle platform, which may differ from other LMS platforms such as Canvas, Blackboard, and Brightspace. Therefore, it might be useful to determine whether results are different or not if the CLDLA model is implemented on other platforms. Third, the sample used in this research was limited to a small group of graduate students in one course. It would be useful to run the CLDLA model for other students in other courses in order to investigate the generalisability and scalability of the CLDLA model. Finally, this study offered potential effectiveness of the CLDLA model to improve online course design since it provided insights on whether students were doing as it was planned in course design. Further studies are recommended to explore the CLDLA model's potential to improve course design.

\section{Disclosure statement}

The authors reported no potential conflict of interest.

\section{Notes on contributor}

Seyyed Kazem Banihashem is a PhD graduate in the field of Educational Technology from Allameh Tabataba'i University, Iran. He currently works as a postdoctoral researcher at Wageningen University and Research, the Netherlands. His research interests include Learning Analytics, Technology Enhanced Learning, Learning Design, Peer Feedback, and Computer-Supported Collaborative Learning (CSCL). 
Mohammadreza Farrokhnia is a PhD candidate at the Education and Learning Sciences Group, Wageningen University and Research, the Netherlands. His research interests include E-Learning, Computer-Supported Collaborative Learning (CSCL), Concept Maps, Educational Technology, Online Learning Environments, and Entrepreneurship Education.

Mehdi Badali is a PhD graduate in the field of Educational Technology from Tarbiat Modares University, Iran. His research interests include E-Learning, Massive Open Online Course (MOOC), and Instructional Design.

Omid Noroozi is a faculty member of Educational Technology at the Education and Learning Sciences Chair Group, Wageningen University and Research, the Netherlands. His research interests include Collaborative Learning, E-Learning and Distance Education, Computer-Supported Collaborative Learning ( $\mathrm{CSCL}$ ), Argumentative Knowledge Construction in $\mathrm{CSCL}$, Argumentation Based CSCL, CSCL Scripts and, Trans activity.

\section{ORCID}

Seyyed Kazem Banihashem (iD http://orcid.org/0000-0002-9978-3783

Mohammadreza Farrokhnia (D http://orcid.org/0000-0002-0150-5372

Omid Noroozi (iD http://orcid.org/0000-0002-0622-289X

\section{References}

Abubakar, A., Abubakar, Y., \& Itse, J. B. (2017). Students' engagement in relationship to academic performance. Journal of Education and Social Sciences, 8(1), 5-9. https://www.jesoc.com/wpcontent/uploads/2017/11/JESOC8_201.pdf

Akçapınar, G., Altun, A., \& Aşkar, P. (2019). Using learning analytics to develop early-warning system for at-risk students. International Journal of Educational Technology in Higher Education, 16(1), 40. https://doi.org/10.1186/s41239-019-0172-z

Banihashem, S. K. (2020). Development and validation of learning environment design model based on the constructivism theory in higher education with a focus on learning analytics [Unpublished doctoral dissertation]. Allameh Tabataba'i University.

Banihashem, S. K., Aliabadi, K., Pourroostaei Ardakani, S., Delavar, A., \& Nili Ahmadabadi, M. R. (2018). Learning analytics: A systematic literature review. Interdisciplinary Journal of Virtual Learning in Medical Sciences, 9(2), 1-10. http://dx.doi.org/10.5812/ijvlms.63024

Banihashem, S. K., Aliabadi, K., Pourroostaei Ardakani, S., Nili Ahmadabadi, M. R., \& Delavar, A. (2019). Investigation on the role of learning theory in learning analytics. Interdisciplinary Journal of Virtual Learning in Medical Sciences, 10(4), 14-27. https://dx.doi.org/10.30476/ijvlms.2019.84294.1001

Broadbent, J., \& Poon, W. L. (2015). Self-regulated learning strategies \& academic achievement in online higher education learning environments: A systematic review. The Internet and Higher Education, 27, 1-13. https://doi.org/10.1016/j.iheduc.2015.04.007

Brown, J. M., Miller, W. R., \& Lawendowski, L. A. (1999). The self-regulation questionnaire. In L. VandeCreek \& T. L. Jackson (Eds..), Innovations in clinical practice: A source book (Vol. 17, pp. 281-292). Professional Resource Press/Professional Resource Exchange. https://psycnet.apa.org/ record/1999-02283-018

Bybee, R. W., Taylor, J. A., Gardner, A., Van Scotter, P., Powell, J. C., Westbrook, A., \& Landes, N. (2006). The BSCS 5E instructional model: Origins and effectiveness. Colorado Springs, Co, 80918. https:// media.bscs.org/bscsmw/5es/bscs_5e_full_report.pdf

Calonge, D. S., Riggs, K. M., Shah, M. A., \& Cavanagh, T. A. 2019. Fostering multiple levels of engagement in higher education environments. In K. Walters \& P. Henry Eds., Using learning analytics to improve engagement, learning, and design of massive open online courses, 76-107. IGI Global. https://doi.org/10.4018/978-1-5225-7470-5.ch004. 
Chaubey, A., \& Bhattacharya, B. (2015). Learning management system in higher education. IJSTEInternational Journal of Science Technology \& Engineering, 2(3), 158-162. https://ijste.org/Article. php?manuscript=IJSTEV2I3050

Chen, B., Chang, Y. H., Ouyang, F., \& Zhou, W. (2018). Fostering student engagement in online discussion through social learning analytics. The Internet and Higher Education, 37, 21-30. https:// doi.org/10.1016/j.iheduc.2017.12.002

Cho, M. H., \& Shen, D. (2013). Self-regulation in online learning. Distance Education, 34(3), 290-301. https://doi.org/10.1080/01587919.2013.835770

Gašević, D., Dawson, S., Rogers, T., \& Gasevic, D. (2016). Learning analytics should not promote one size fits all: The effects of instructional conditions in predicting academic success. The Internet and Higher Education, 28, 68-84. https://doi.org/10.1016/j.iheduc.2015.10.002

Heller, N. (2020). Pervasive learning analytics for fostering learners' self-regulation [doctoral dissertation, ludwig maximilian university of munich]. Ludwig Maximilian University of Munich. https://edoc.ub.uni-muenchen.de/26428/

Hodson, D., \& Hodson, J. (1998). From constructivism to social constructivism: A vygotskian perspective on teaching and learning science. School Science Review, 79(289), 33-41.

Hofmann, W., Schmeichel, B. J., \& Baddeley, A. D. (2012). Executive functions and self-regulation. Trends in Cognitive Sciences, 16(3), 174-180. https://doi.org/10.1016/j.tics.2012.01.006

Holmes, W., Nguyen, Q., Zhang, J., Mavrikis, M., \& Rienties, B. (2019). Learning analytics for learning design in online distance learning. Distance Education, 40(3), 309-329. https://doi.org/10.1080/ 01587919.2019 .1637716

$\mathrm{Hu}, \mathrm{X} ., \mathrm{Ng}$, J., Tsang, K. K., \& Chu, S. K. (2020). Integrating mobile learning to learning management system in community college. Community College Journal of Research and Practice, 44(10-12), 722-737. https://doi.org/10.1080/10668926.2019.1640146

Ifenthaler, D., Gibson, D., \& Dobozy, E. (2018). Informing learning design through analytics: Applying network graph analysis. Australasian Journal of Educational Technology, 34(2), 117-132. https:// doi.org/10.14742/ajet.3767

Jonassen, D. (1999). Designing constructivist learning environments. In C. Reigeluth (Ed.), Instructional-design theories and models: A new paradigm of instructional theory (pp. 215-239). University Park: Pennsylvania State University.

Kahn, P., Everington, L., Kelm, K., Reid, I., \& Watkins, F. (2017). Understanding student engagement in online learning environments: The role of reflexivity. Educational Technology Research and Development, 65(1), 203-218. https://doi.org/10.1007/s11423-016-9484-z

Kalenda, J., \& Vávrová, S. (2016). Self-regulated learning in students of helping professions. Procedia-Social and Behavioral Sciences, 217, 282-292. https://doi.org/10.1016/j.sbspro.2016. 02.086

Khalifeh, G., Noroozi, O., Farrokhnia, M., \& Talaee, E. (2020). Higher education students' perceived readiness for computer-supported collaborative learning', multimodal technologies and interaction. Multimodal Technologies and Interaction, 4(2), 11. https://doi.org/10.3390/mti4020011

Kim, D., Yoon, M., Jo, I. H., \& Branch, R. M. (2018). Learning analytics to support self-regulated learning in asynchronous online courses: A case study at a women's university in South Korea. Computers \& Education, 127, 233-251. https://doi.org/10.1016/j.compedu.2018.08.023

Knight, S., Buckingham Shum, S., \& Littleton, K. (2014). Epistemology, assessment, pedagogy: Where learning meets analytics in the middle space. Journal of Learning Analytics, 1(2), 23-47. https://doi. org/10.18608/jla.2014.12.3

Liu, C., Lim, R., Taylor, S., \& Calvo, R. A. (2019). Students' behavioral engagement in reviewing their tele-consultation feedback within an online clinical communication skills platform. Computers in Human Behavior, 94, 35-44. https://doi.org/10.1016/j.chb.2019.01.002

Mameli, C., \& Passini, S. (2017). Measuring four-dimensional engagement in school: A validation of the student engagement scale and of the agentic engagement scale. TPM: Testing, Psychometrics, Methodology in Applied Psychology, 24(4), 423-436. http://dx.doi.org/10.4473/TPM24.4.4

Martin, F., \& Bolliger, D. U. (2018). Engagement matters: Student perceptions on the importance of engagement strategies in the online learning environment. Online Learning, 22(1), 205-222. http://dx.doi.org/10.24059/olj.v22i1.1092 
Merrill, M. D. (2002). First principles of instruction. Educational Technology Research and Development, 50(3), 43-59. https://doi.org/10.1007/BF02505024

Pardo, A., Han, F., \& Ellis, R. A. (2016). Combining university student self-regulated learning indicators and engagement with online learning events to predict academic performance. IEEE Transactions on Learning Technologies, 10(1), 82-92. https://doi.org/10.1109/TLT.2016.2639508

Pardo, A., Jovanovic, J., Dawson, S., Gašević, D., \& Mirriahi, N. (2019). Using learning analytics to scale the provision of personalised feedback. British Journal of Educational Technology, 50(1), 128-138. https://doi.org/10.1111/bjet.12592

Persico, D., \& Pozzi, F. (2015). Informing learning design with learning analytics to improve teacher inquiry. British Journal of Educational Technology, 46(2), 230-248. https://doi.org/10.1111/bjet. 12207

Reeve, J., \& Tseng, C. M. (2011). Agency as a fourth aspect of students' engagement during learning activities. Contemporary Educational Psychology, 36(4), 257-267. http://dx.doi.org/10.1016/j.cedp sych.2011.05.002

Roll, I., \& Winne, P. H. (2015). Understanding, evaluating, and supporting self-regulated learning using learning analytics. Journal of Learning Analytics, 2(1), 7-12. https://doi.org/10.18608/jla. 2015.21.2

Russell, D., \& Warner, R. (2017). Motivational intermediaries of self-regulation among university students. Journal of Applied Research in Higher Education, 9(3), 448-464. https://doi.org/10.1108/ JARHE-08-2015-0062

Toro-Troconis, M., Alexander, J., \& Frutos-Perez, M. (2019). Assessing student engagement in online programmes: Using learning design and learning analytics. International Journal of Higher Education, 8(6), 171-183. https://doi.org/10.5430/ijhe.v8n6p171

Trowler, V. (2010). Student engagement literature review. The Higher Education Academy, 11(1), 1-15. https://pure.hud.ac.uk/en/publications/student-engagement-literature-review

Viberg, O., Khalil, M., \& Baars, M. (2020, March 23-27). Self-regulated learning and learning analytics in online learning environments: A review of empirical research. In In proceedings of the tenth international conference on learning analytics \& knowledge (pp. 524-533). ACM, New York, United States. https://doi.org/10.1145/3375462.3375483.

Vytasek, J. M., Patzak, A., \& Winne, P. H. 2020. Analytics for student engagement. In M. Virvou, E. Alepis, \& G. A. Tsihrintzis Eds., Machine Learning Paradigms, 23-48. Springer, Cham. https://doi. org/10.1007/978-3-030-13743-4_3.

Wiley, K. J., Dimitriadis, Y., Bradford, A., \& Linn, M. C. (2020, March 23-27). From theory to action: Developing and evaluating learning analytics for learning design. In In Proceedings of the Tenth International Conference on Learning Analytics \& Knowledge (pp. 569-578). https://doi.org/10. 1145/3375462.3375540. ACM, New York, United States.

Winne, P. H. (2017). Learning analytics for self-regulated learning. In C. Lang, G. Siemens, \& A. Wise, (Eds..), Handbook of learning analytics (pp. 241-249). Society for Laening Analytics Research (SOLAR). https://doi.org/10.18608/hla17.021

Wise, A. F. (2014, March 24-28). Designing pedagogical interventions to support student use of learning analytics. In In Proceedings of the Fourth International Conference on Learning Analytics And Knowledge (pp. 203-211). ACM, New York, United States. https://doi.org/10.1145/2567574. 2567588.

Wong, J., Baars, M., Davis, D., Van Der Zee, T., Houben, G. J., \& Paas, F. (2019). Supporting self-regulated learning in online learning environments and MOOCs: A systematic review. International Journal of Human-Computer Interaction, 35(4-5), 356-373. https://doi.org/10.1080/ 10447318.2018.1543084 